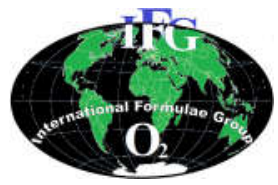

Int. J. Biol. Chem. Sci. 10(5): 2015-2024, October 2016

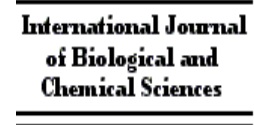

ISSN 1997-342X (Online), ISSN 1991-8631 (Print)

Original Paper http://ajol.info/index.php/ijbcs http://indexmedicus.afro.who.int

\title{
Current situation of fish farming in Togo
}

\author{
Amakoé ADJANKE ${ }^{1,2^{*}}$, Kokou TONA ${ }^{1}$, Prudencio T. AGBOHESSI ${ }^{2}$, \\ Ibrahim Imorou TOKO $^{2}$ and Messanvi GBEASSOR ${ }^{1}$ \\ ${ }^{1}$ Laboratory of Animal Physiology, Faculty of Science (FDS), University of Lome, \\ 01 P.O. Box 1515 Lome, Togo. \\ ${ }^{2}$ Aquaculture and aquatic Ecotoxicology Research Unit, Faculty of Agronomy (FA), \\ University of Parakou (UP), 03 PoBox 61, Parakou, Benin. \\ *Corresponding author; E-mail: a_amakoe@hotmail.fr; Tel.: (+228) 90356531.
}

\section{ACKNOWLEDGMENTS}

The authors express their gratitude to the PARRAF (Programme d'Appui à la Recherche en Réseau en Afrique) and PPAAO (Programme de Productivité Agricole en Afrique de l'Ouest) programs for their financial support of this study.

\begin{abstract}
In Togo, fish farming is faced with several problems which oblige farmers to develop local production techniques that explain the low level of production. To assess the current situation, a survey was conducted to collect information on this activity in 91 Togolese fish farms located in the five regions of the country. The survey has shown the existence of two production systems, namely the extensive majority system (87.91\%) practiced in ponds and water reservoirs and the semi intensive system (12.09\%) implemented in tanks and ponds. The lack of accurate data has made it difficult to estimate production. Nevertheless, eight fish species are found in these environments in which tilapia (Oreochromis niloticus) and the African cat fish (Clarias gariepinus) represent $80 \%$ of farmed species. Feed, representing over $50 \%$ of fish production cost, remains the major constraint on the development of this activity. However, agro-industrial by-product resources were available depending on region and are recoverable for use as fish feed. This is the case for palm kernel meal which was abundant and little studied in Togo. Sociologically, fish farming was more a matter of group $(61.54 \%)$ than individual $(38.46 \%)$ activity. The extensive fish farming system deserves to be improved and agro-industrial by-products analyzed and valued for the promotion of fish farming in Togo.
\end{abstract}

(C) 2016 International Formulae Group. All rights reserved.

Keywords: Fish, food, fish farming infrastructure, agro-industrial by-products, palm kernel meal.

\section{INTRODUCTION}

Annual piscatorial production is about 25,000 tons in Togo (DPA, 2011). This production covers about $40 \%$ of Togolese animal protein requirement (Brummett et al., 2008), the greater part being provided by massive imports from other African and also Asian countries (FAO, 2012). Moreover, national production and imports might provide $13 \mathrm{~kg}$ per capita per year (DPA, 2011), compared with $16 \mathrm{~kg}$ in Sub-Saharan Africa (WFC, 2004). So, fish stocks are 
overexploited leading to the scarcity and high cost of fish products and massive importation (FAO, 2002). Aquaculture development appears to be one of the best ways of reducing Togo protein deficit and ensure household food security by improving incomes and food quality. Natural potentialities (rivers, lakes, the sea, lagoons) and local climatic conditions are favorable for fish farming. In Togo, fish farming is practiced using various infrastructures like ponds, tanks and water reservoirs (ITRA, 2005). Also, agricultural and agro-industrial by-products are available for feeding fish. Despite this, fish farming has not yet attained a viable economic dimension in Togo. The production of 20 tons per year is very small (ITRA, 2005). It becomes necessary to analyze the potentials and constraints on the development of aquaculture in the country.

\section{MATERIALS AND METHODS}

\section{Study area}

This study was conducted on fish farms in Togo. Located between the 6th and 11th parallels north, Togo is a West African country, covering an area of $56,600 \mathrm{~km}^{2}$ (MAEP, 2003). Its population is estimated at $5,753,324$ inhabitants in 2010 (DGSCN, 2011). Togo is divided into two climatic zones: a sub-equatorial climate with two rainy seasons alternating with two dry seasons in the south; a sudan climate with one rainy season and one dry season in the north. Average annual rainfall is $1,151 \mathrm{~mm}$ and temperatures are warm the whole year and range from 27 to $29^{\circ} \mathrm{C}$ (DGMN, 2008). Soils are divided into three major groups and vegetation is characterized by forests and savannas that interlock to form a mosaic (MAEP, 2003). Togo is drained by a $1,780 \mathrm{~km}$ river system, the main rivers (the Oti, the Mono, the Haho and the Zio) are bordered by floodplains and lowlands which are generally marginal land often uncultivated for agricultural production (ITRA, 2003). The alternation of seasons causes a change in the flow of most of the rivers. This river system, in association with a lagoonal system in the south $\left(64 \mathrm{~km}^{2}\right)$ and 30,000 ha of dams are suitable for fish farming (ITRA, 2003).

\section{Methodology}

Information presented and discussed in this document is from data collected in several stages all over the country from December 2013 to March 2014. The methodology adopted in this study was based on two main points:

- Documentary research and analysis;

- Gathering information from actors in the aquaculture industry.

\section{Documentary research and analysis}

Existing documentation in research and extension facilities was exploited. Specifically, the Fisheries and Aquaculture Department (DPA), the Ministry of Agriculture, Livestock and Fisheries, University libraries, the Development Study Society of Togo (SOTED), the Livestock Department (DE), the Togolese Agricultural Research Institute (ITRA), the Council and Technical Support Institute (ICAT), the Department of Statistics, the Data processing and Documentation (DSID) were all consulted. Websites were other important sources of information. The literature search focused on the interaction between fish farming systems, fish numbers in breeding, fish feeding patterns and fish nutritional needs depending on developmental stage and physiological state. This literature also focused on production units and actors in the aquaculture industry. Information collected during this phase was used to complement and consolidate collected field data.

\section{Phase of information gathering from actors}

This phase is conducted as a survey of industry actors. First, a questionnaire for fish farmers and an interview guide for technical support services and resource persons were developed. The questionnaire and interview guide were used to gather information on operator identification and fish farm location, 
various livestock infrastructure, species of fish bred, fish feeding practices, production, fish marketing and difficulties encountered in the activity. The sector has 102 farms according to the census available to the Fisheries and Aquaculture Department (DPA). The questionnaires were given to a sample of more than $90 \%$ of the fish farmers in the five regions of Togo; $70 \%$ in the Plateau region, $13 \%$ in the Maritime region and the remaining $17 \%$, in the other regions. The administration of the questionnaires and interview guides were performed by trained investigators.

\section{Data processing}

Collected data was used to make a list of the different fish species bred, food items available in the country and fish rearing systems in Togo. The Access and Excel 2007 software made it possible to encode collected data and to set up tables and figures.

\section{RESULTS}

\section{Fish breeding areas in Togo}

The investigation revealed that Togo had large spaces with fish farming vocation close to rivers. Figure 1 shows the concentration and geographical locations of active and inactive fish farms in Togo. They were mostly concentrated in the plateau region, which alone accounts for more than $78 \%$ of farms surveyed. Table 1 shows that the majority of farms were located on flat shallow low ground on sandy clay soil; with disparities between different regions of the country.

Water supply for fish farming was from rivers $(67.5 \%)$, which were sometimes barred to raise their level in order to provide free water to livestock infrastructure. Other units were supplied with reservoir $(25 \%)$ or well water $(7.5 \%)$. Reservoir water was more common in the Kara and Central regions $(100 \%)$ followed by the Savannah region (66.67\%), while rivers supplied water to most of the fish units in the Plateau $(77.06 \%)$ and Maritime (53.85\%) regions. Annual availability of water for fish farming was related to the duration of rainfall. This varied from 4 to 6 months in the Central, Kara and Savannah regions; 6 to 8 months in the Maritime region and 8 to 10 months in the Plateau region. But rainfall duration showed a downward trend over the past ten years due to climate change; with consequences for fish production.

Table 2 shows that in the Plateau region, containing the majority of farms, average infrastructure per farm was low while average surface water level for aquaculture was higher compared to other regions in the country.

\section{Livestock infrastructure}

In Togo, the main infrastructure identified for fish farming during the investigation included ponds $(80 \%)$, cement tanks (13\%) and water reservoirs (7\%).

\section{Ponds}

Ponds were predominant in fish production in Togo. The surface areas of ponds varied between 50 and $1400 \mathrm{~m}^{2}$ with a depth between 0.4 and $1 \mathrm{~m}$. Our results revealed two types of ponds, drainable ponds (67\%) concentrated in the Plateau region and non- drainable ponds (33\%) in the other regions. Non-drainable ponds were smaller than drainable ponds. The Plateau and Maritime regions accounted for most of the surveyed ponds with $64 \%$ and $18 \%$ respectively. The modes of access to land identified in this study were purchase (36.05\%), inheritance $(32.56 \%)$ and donation $(19.75 \%)$. Most ponds were built manually (68.29\%). Some farmers have used an excavator to build their ponds $(20.73 \%)$, but mixed methods (machine and manual labor) were also observed (10.98\%). However, the skills required for their construction and use were unfortunately still lacking.

\section{Tanks}

Cement tanks, 48 in number, were located in the Maritime (58\%), Plateau (34\%) and Savannah regions ( $8 \%$ ). Their total area is estimated at $7,500 \mathrm{~m}^{2}$ with an average size 
between 10 and $200 \mathrm{~m}^{2}$. In this study, tank owners noted that lack of adequate land and water source lead them to choose tanks.

\section{Water reservoirs}

We had identified 23 water reservoirs, the majority of them $(82 \%)$ in the Plateau region. Their total surface area was estimated at 28.5 ha. They were used for extensive fish farming. They usually received fish by runoff. Some of these dams were drainable through the assistance of a monk but the impossibility of water level control made their exploitation difficult.

\section{Production techniques}

In Togo, there were two culture systems such as extensive farming $(87.91 \%)$ and semi-intensive farming (12.09\%). Extensive fish farming was practiced in ponds and water reservoirs and it is characterized by the presence of different species with different sizes in the same pond supplied with little feed. In Togo, the proportion of extensive fish farms was $100 \%$ in the Central, Kara and Savannah regions. In the Maritime and Plateau regions, this breeding technique is practiced by $88.89 \%$ and $92.31 \%$ respectively of surveyed fish farms. $84.21 \%$ of ponds were stocked after construction. The fish were fed with kitchen remains, coarse food and greenery. It was the prerogative of fishing groups. Harvesting in water reservoirs was often difficult because the reservoir was primarily intended to be a source of drinking water and not for aquaculture. The type of semi-intensive fish farming practiced in Togo consisted in water level reallocation depending on the development stage of fish (fingerlings, juveniles, parents and merchants) fed on a food supplement made of agricultural and agro industrial by-products. This type of farming was rare and found in the Savannah (66.67\%), Plateau (9.86\%) and Maritime $(15.38 \%)$ regions. It is practiced mainly in tanks and some ponds. The care given to fish in this system allowed for mean yield but the owners had no data on the quantity of feed used and fish density. Cage fish farming was introduced in Lake Nangbeto by Nodis FISH Company.

\section{Fish feeding}

Food resources available for fish existed in all regions of the country. Most often, these were conventional ingredients that were used for food production. The most commonly used ingredients in Togo were rice bran (20\%), fish meal (15\%), corn flour (8\%), soybean $(8 \%)$, roasted soybean $(7 \%)$, soybean meal $(8 \%)$ and cubed bran (8\%). Since nutritional requirements of fish are high in crude protein and low in dietary fiber, only some feedstuffs could be incorporated in fish feed. In the light of the survey results, it appeared that protein ingredients are generally less used than other groups of ingredients with a national average of $23.64 \%$ and $10 \%$ only in the Central region (Figure 2). Seventy-six percent of respondents sourced their ingredients from local markets. Only 13.19\% of fish farmers feed their fish with commercial feed, this confirms the extensive nature of fish farming in Togo mainly based on the mixed breeding mode. In local markets, ingredients such as beer malt, rice bran, maize, oil cakes including palm kernel are available. Palm kernel meal, previously little used $(6.25 \%$ in the Maritime and $1.31 \%$ in Plateau regions); $0 \%$ in other regions could be a real alternative source of protein. Palm kernel meal was available and produced hygienically by Ave Palm which produced about 10,000 tons per year. After analysis of the national food supply, Table 3 lists the products and recoverable agro-industrial by-products usable in fish farming by region in Togo. We can add to this list a vitamin mineral complex to obtain a balanced diet. The feed was mostly manufactured by operators $71.43 \%$ of whom considered their feed to be acceptable. The feed was generally in the form of flour (over $75 \%$ ) and fed to the fish manually; thus allowing regular monitoring of fish behavior. Greenery was often provided as leaves. 


\section{Harvest and equipment}

Harvest is the operation which ends each production cycle. It is done using a seine net in a pond or reservoir while a simple net allows easier harvesting in tanks. Over $75 \%$ of fish farms didn't have a net. To harvest fish about $67 \%$ used mosquito nets which tore in the process. In the mixed breeding method, it is good to make a partial harvest by taking the big fish at regular intervals. Some fish farms had never harvested to date while others did it every 3-4 months. Fish is usually sold fresh, in lots when it reaches the marketable size (about $200 \mathrm{~g}$ ) at farm site by women who organize sale to households. Furthermore, fish farmers did not record losses since production couldn't meet increasing customer demand.

\section{Fish farm production and bred species}

The lack of proper equipment (balance) made it difficult to estimate national fish production and the quantity harvested for sale. Nationally, tilapia (Oreochromis niloticus) was the most important species of fish in terms of number bred (Figure 3), followed by catfish (Clarias gariepinus) bred in the
Maritime, Plateau and Savannah regions. These two species represent about $80 \%$ of fish bred in Togo. Other species were also encountered (Figure 3); they came from the natural environment and were brought into ponds by water runoff.

\section{Human actors}

In Togo, the fish farming industry had no professional organization. About 500 people led this activity individually or in groups and nearly $61 \%$ of Togolese fish farms were installed and managed by groups. In addition to the fish farmers who constitute the bedrock and most important actors in the industry, we also had producers and importers of livestock machinery and fry, feed manufacturers, feedstuff suppliers, service providers, frozen fish importers, fish traders, training officers, training facilities and research institutions. In Togo, we had fish production units and feed manufacturing units. These were simple mills (grinding and mixing) rather than a veritable fish feed industry. Therefore, they were used by very few producers.

Table 1: Site distribution (\%) according to natural characteristics and the region.

\begin{tabular}{llcccccc}
\hline Characteristics & Maritime & Plateau & Central & Kara & Savannah & National \\
\hline \multirow{4}{*}{ Relief } & Hollows & 53.85 & 53.63 & 50 & 100 & 66.67 & 63.99 \\
& Mountain & 0 & 2.90 & 0 & 0 & 0 & 2.25 \\
& Plain & 46.15 & 17.39 & 0 & 0 & 0 & 20.22 \\
\multirow{2}{*}{ Total } & Plateau & 0 & 26.09 & 50 & 0 & 33.33 & 22.47 \\
& & 100 & 100 & 100 & 100 & 100 & 100 \\
\multirow{2}{*}{ Valleys } & Deep & 9.09 & 19.40 & 0 & 0 & 33.33 & 17.86 \\
& Flat & 18.18 & 68.66 & 100 & 50 & 33.33 & 60.71 \\
& Truncated & 72.73 & 11.94 & 0 & 50 & 33.33 & 21.43 \\
\multirow{5}{*}{ Soil } & & 100 & 100 & 100 & 100 & 100 & 100 \\
& Clayey & 38.46 & 20.59 & 100 & 100 & 0 & 26.14 \\
& Sotal & 30.77 & 10.29 & 0 & 0 & 33.33 & 13.64 \\
& Sandy & 30.77 & 69.12 & 0 & 0 & 66.67 & 60.23 \\
& & 100 & 100 & 100 & 100 & 100 & 100 \\
\hline
\end{tabular}


Table 2: Average number of fish farming infrastructure by farm and their mean area by region.

\begin{tabular}{lcc}
\hline Region & Number & Area in $\mathbf{~ m}^{\mathbf{2}}$ \\
\hline Maritime & 8 & 3463.66 \\
Plateau & 3 & 4945.17 \\
Central & 11 & 459.00 \\
Kara & 2 & 300.50 \\
Savannah & 6 & 969.59 \\
\hline National & 6 & 2027.58 \\
\hline
\end{tabular}

Table 3: Food resources locally available and valuable for fish farming according to regions in Togo.

\begin{tabular}{|c|c|}
\hline Region & Available resources \\
\hline Maritime & $\begin{array}{l}\text { Maize, soy grain, roasted and cake of soy, rice bran, palm kernel cake, palm oil, } \\
\text { moringa leaf, fish meal, cotton and peanut cake, dried cassava, cubed bran, malt and } \\
\text { yeast of beer, droppings of poultry, kitchen rests, maggots, blood meal, shell of oyster }\end{array}$ \\
\hline Plateau & $\begin{array}{l}\text { Maize, soy grain, roasted and cake of soy, rice bran, palm kernel cake, palm oil, } \\
\text { moringa leaf, fish meal, cotton and peanut cake, dried cassava, cubed bran, malt of } \\
\text { beer, kitchen rests, blood meal, droppings of poultry, animals scraps, shell of oyster }\end{array}$ \\
\hline Central & $\begin{array}{l}\text { Maize, soy grain, roasted and cake of soy, rice bran, malt of beer, droppings of } \\
\text { poultry, dried cassava, kitchen rests, shell of oyster }\end{array}$ \\
\hline Kara & $\begin{array}{l}\text { Maize, soy grain, roasted and cake of soy, rice bran, dried cassava, malt and yeast of } \\
\text { beer, droppings of poultry, kitchen rests, shell of oyster }\end{array}$ \\
\hline Savannah & $\begin{array}{l}\text { Maize, soy grain, roasted and cake of soy, rice bran, dried cassava, droppings of } \\
\text { poultry, kitchen rests, shell of oyster }\end{array}$ \\
\hline
\end{tabular}

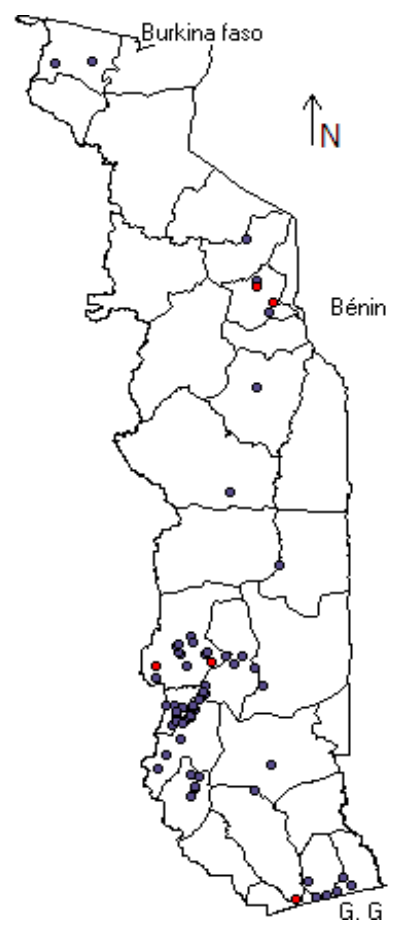

Figure 1: Geographical location of fish farms in Togo. 


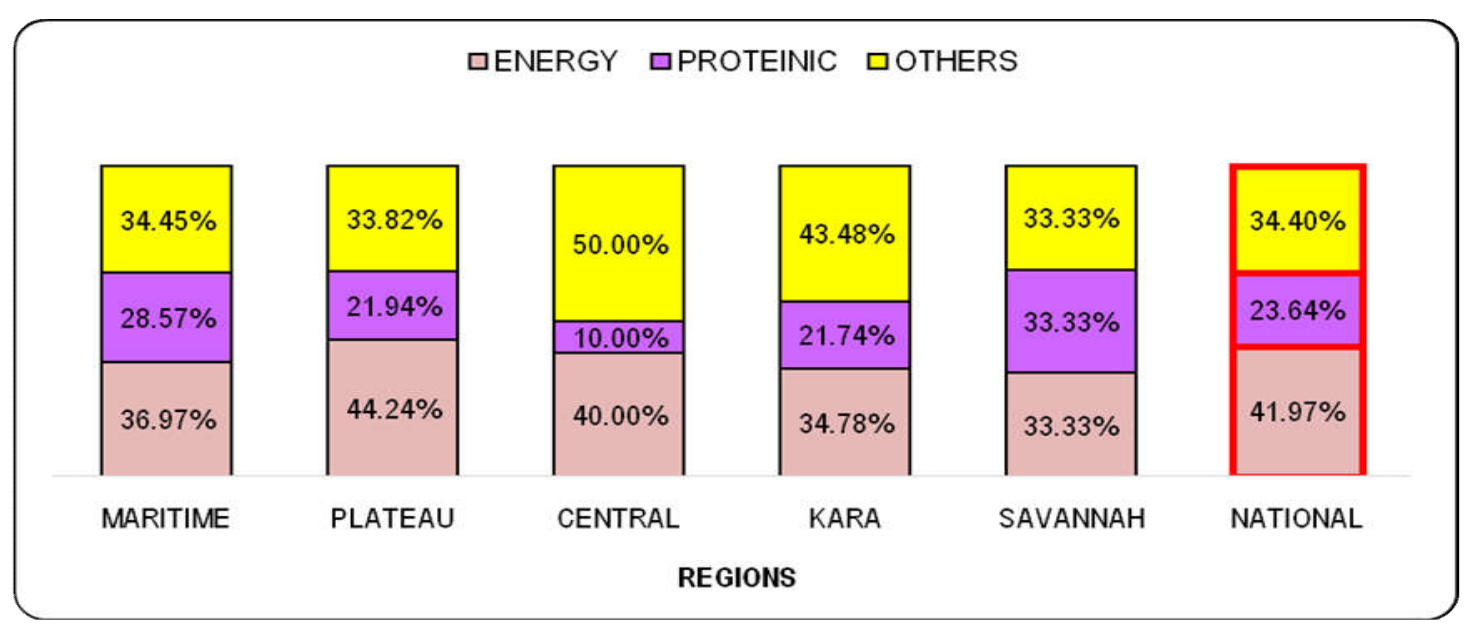

Figure 2: Distribution of feedstuffs used locally in Togo.

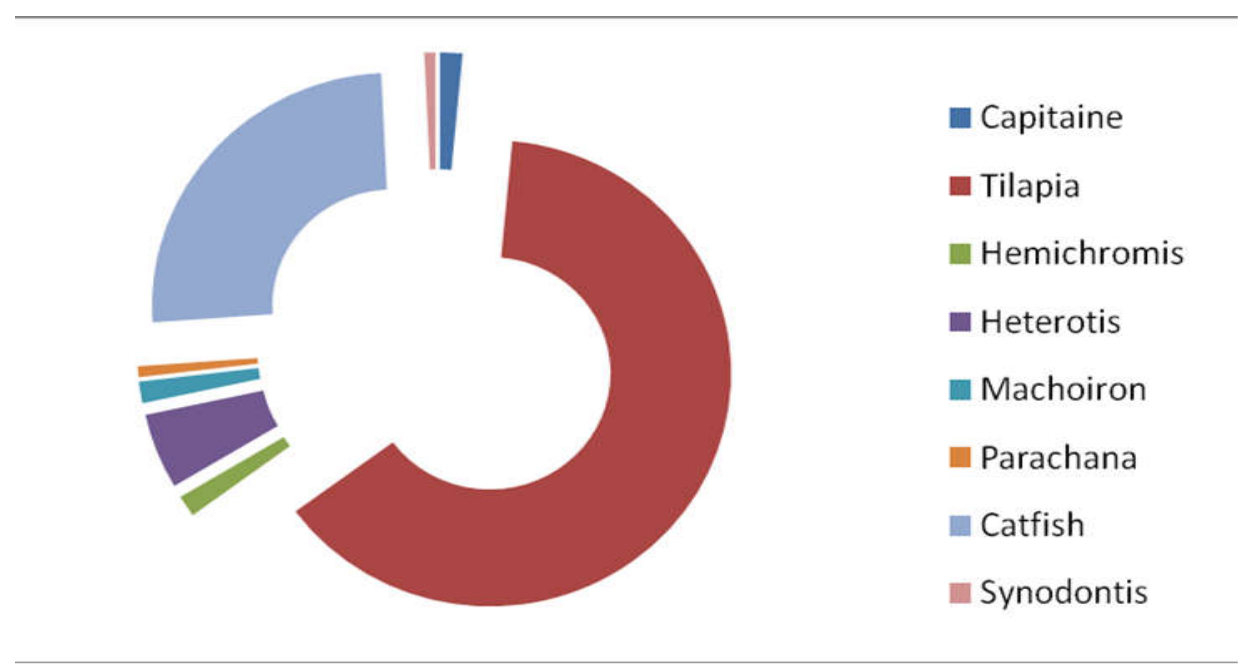

Figure 3: Proportion of fish species bred nationally.

\section{DISCUSSION}

Breeding systems determine the mode of space utilization, relations between livestock and vegetable production and modes of production valorization (Coly et al., 2011). Water availability is one condition for sustainable fish farming (Lacroix, 2004). In Togo, there is a dense river network of about $1,780 \mathrm{~km}$ with many rivers (MAEP, 2003). Given the requirements of natural sites of surveyed fish farms, they are concentrated in the Plateau region, which offers a huge natural potential for aquaculture. This is one of the most conducive regions to develop aquaculture in freshwater. It is drained by more than 40 rivers, streams, waterfalls that flow continuously and shelter of the big Nangbeto Lake (FAO, 2012). The peculiarity of the Plateau region can be used to professionalize the industry. However, to ensure sustainable fish farm exploitation, site appropriation is required (Fitzsimons and Looker, 2013). The commonest access modes observed are purchase, inheritance and 
donation which constitute a guarantee for sustainable fish farming development in Togo. Concerning fish farming infrastructure, a FAO study, conducted in 2011, enumerated 348 ponds more than half of which were nonfunctional (FAO, 2012). But in this study, we identified 290 functional ponds, covering a total area of 18.5 ha. This reflects a renewed interest in this activity compared to the previous situation. The type of pond to set up depends on topographic constraints and depth of water table (Toko et al., 2011). It must be impermeable to water and provide a favorable environment for fish development (Toko et al., 2011). Most of the ponds and water reservoirs were stocked with fingerlings or parents generally coming from the natural environment. Farmers do not master fish density in a pond. This poses problems of overcrowding, lack of living space, food rationing and pathological risk (Kpogue and Fiogbe, 2014). Output is low, about 300 $\mathrm{kg} / \mathrm{ha} /$ year (FAO, 2012). Tanks are used in the semi-intensive fish production method as at the Tonon Foundation in Benin. They are used for the production of larvae and fish fry, treatment of androgen sex reversal (Montchowui et al., 2012), but mainly for growth and production of market-size fish (Akinwole et al., 2014). This farming method has the advantage of requiring little space compared to pond culture. It allows an effective control of environmental conditions, very precise management of production and staff training (Akinwole et al., 2014). Tanks and some drainable ponds are stocked with fish by farmers and production is more controlled with feed supply or fertilizer used for natural food development (Lacroix, 2004). In this case, average yield is about $50 \mathrm{~kg} / 100$ $\mathrm{m}^{2} /$ year (FAO, 2012). Togo's aquaculture production is about twenty tons per year (Ahoedo, 2009). This production is low despite the aquaculture potential. It is faced with several constraints including feeding. However, feed is the main constraint on the development of fish farming (Gourene et al., 2002). In addition to its nutritional and microbiological qualities, food greatly influences the zoological performance of fish and farm profitability. The main issues affecting fish supply relate to their food needs and permanent availability of feedstuffs (Richter et al., 2003). Ration formulation is based on nutritional requirements of fish according to the nutritional value of ingredients (El-Sayed, 2006). Fish farmers investigated use different types of ingredients in food preparation. This is recommended not only to reduce food cost but also to improve its nutritional quality (Bamba et al., 2014). It would be better to select local raw materials like palm kernel meal according to their price and availability to make fish feed. This ingredient is cheap and largely available. Few fish farmers produce feed taking into account the requirements of fish; this confirms the extensive nature of aquaculture in Togo which is mainly based on the mixed breeding mode. Although flour based feed is cheaper, their disadvantage is the wastage that occurs during feeding. It would be interesting to initiate granulation that will allow farmers to improve their product. This technique consists in converting a flour based feed into pellets and it has technical advantages (loss reduction), zootechnique (balance of components, better palatability and digestibility) and health (less infection and respect of the ecosystem) (Bamba et al., 2014). Pond fertilization with compost for the development of plankton (Lacroix, 2004) is also observed in various ways in the regions. This practice could allow feed cost reduction and improve the extensive fish farming system. With good compost, feed made with rice or wheat bran would be sufficient for fish production in ponds. The lack of adequate fish feed has prolonged the production cycle to the point that some fish units had never harvested till now. Others, for socio-economic welfare reasons made early harvests (3-4 months), which normally should occur every 6 months (Toko et al., 2011). The improvement and development of production conditions in extensive fish farming is the sustainable alternative for reducing the country's deficit of fish products. In fact, infrastructure and operators are available but 
they lack professionalism since fish farming was a secondary activity, operators being first farmers, breeders, business men, etc. The improvement of extensive fish breeding implies an awakening of the conscience of operators on the profitability of fish farming, setting up a modular training system and retraining sessions coupled with production optimization based on a rational and balanced feed aimed at reducing the cost of locally available feed inputs.

\section{Conclusion}

Extensive farming ponds were the most encountered breeding system in Togo. Its production is low because of poor training and management (stocking density, feeding, water renewal, etc.). Climatic, soil, hydrographic, social and agricultural potentials exist for fish farming promotion. It is therefore important to train fish farmers and do research mainly on feed and ingredients like palm kernel meal in order to optimize production of various systems and promote their intensification in Togo.

\section{CONFLICT OF INTERESTS}

The authors declare that there is no conflict of interests in relation to this article.

\section{AUTHORS' CONTRIBUTIONS}

$\mathrm{AA}$ is the principal investigator and was involved in all phases of the work of this study, the design of themes, the conduct of the investigation, the analysis and the interpretation of data and writing of the article. KT, IIT and MG contributed to the development of the questionnaire and correction of the article. PTA took part in the analysis and interpretation of the data and correction of the article.

\section{REFERENCES}

Ahoédo K. 2009. Situation de l'aquaculture au Togo. Communication à l'Atelier de validation du Document du Projet de Développement de l'Aquaculture au Togo. Lomé, 12p.
Akinwole AO, Dauda AB, Oredein TA. 2014. Effect of aeration on selected water quality parameters in freshwater fish culture. Int. J. Biol. Chem. Sci., 8(6): 2858-2865.

DOI: http://dx.doi.org/10.4314/ijbcs.v8i6.42

Bamba Y, Ouattara N, Ouattara S, Ouattara A, Gourene G. 2014. Effect of diets containing cocoa bean shell and coconut oil cake on the growth of Oreochromis niloticus (LINNE, 1758) in pond. Int. J. Biol. Chem. Sci., 8(4): 1368-1380. DOI: http://dx.doi.org/10.4314/ijbcs.v8i4.2

Brummett RE, Lazard J, Moehl J. 2008. African aquaculture: Realizing the potential, Food Policy, DOI:10.1016/j.foodpol.2008.01.005

Coly I, Diome F, Dacosta H, Malou R, Akpo IE. 2011. Typologie des exploitations agropastorales du terroir de la NEMA (Sénégal, West Africa). Int. J. Biol. Chem. Sci., 5(5): 1941-1959. DOI : http://dx.doi.org/10.4314/ijbcs.v5i5.15

DGMN. 2008. Données météorologiques: pluviométrie, température, évaporation et humidités relatives. Fichiers Excel, Lomé.

DGSCN. 2011. Recensement général de la population et de l'habitat. Résultats définitifs. Lomé-Togo.

DPA. 2011. Situation de référence de la pisciculture au Togo. Document d'information. Projet TCP/TOG/3305, Lomé, $4 \mathrm{p}$.

El-Sayed AFM. 2006. Tilapia Culture, CABI Publishing, Oxfordshire.

FAO. 2002. Production halieutique mondiale par capture et aquaculture, par pays, A-0 (a). Regional Fishery Bodies, Commitee for inland fisheries of Africa. www.fao.org/fi/body/rfb/CIFA.

FAO. 2012. Stratégie nationale et plan d'action de développement de l'aquaculture au Togo. Projet TCP/TOG/3305. FAO, Rome.

Fitzsimons J, Looker M. 2013. Innovative approaches to land acquisition and conservation management: the case of 
Fish River Station, Northern Territory. Innovation in establishment. 78-85

Gourène G, Kobena KB, Vanga AF. 2002. Etude de la rentabilité des fermes piscicoles dans la région du moyen Comoé. Rapport Technique, Université Abobo-Adjamé, Abidjan, Côte d'Ivoire, 9-22.

ITRA. 2003. Les bas-fonds au Togo: caractéristiques-mise en valeur et contraintes-perspectives. Rapport final, ITA, Lomé.

ITRA. 2005. Productions animales au Togo ; Situation de référence, 37-89.

Kpogue D, Fiogbe E. 2014. Optimum stocking density for Parachanna obscura larvae fed at its optimum ration. Int. J. Biol. Chem. Sci., 6(3). DOI: http://dx.doi.org/10.4314/ijbcs.v6i3.32

Lacroix E. 2004. Pisciculture en zone tropicale. GFA Terra Systems, pp13100.

MAEP. 2003. Etat des ressources génétiques animales au Togo. Rapport National. $85 \mathrm{p}$
Montchowui E, Agadjihouede H, N'tcha E, Laleye P. 2012. Effets de milieux d'élevage sur la survie et la croissance des juvéniles de la carpe africaine, Labeo parvus Boulenger, 1902. Int. J. Biol. Chem. Sci., 6(5): 2131-2138. DOI: http://dx.doi.org/10.4314/ijbcs.v6i5.20

Richter N, Siddhuraju P, Becker K. 2003. Evaluation of nutritional quality of moringa (Moringa oleifera Lam.) leaves as an alternative protein source for Nile tilapia (Oreochromis niloticus L.). Aquaculture, 217: 599-611.

Toko II, Eloi Y. Attakpa Baco NM, Gouda AI. 2011. Analyse des systèmes piscicoles dans la Vallée du Niger (Nord Bénin). Int. J. Biol. Chem. Sci., 5(5): 1993-2003. http://www.ajol.info/index.php/ijbcs/arti cle/view/77137

World Fish Center. 2004. Poissons et l'Afrique sub-saharienne (ASS) - un instantané. In Extrait de documents du Fish for All and NEPAD Summit, Abuja (Nigeria). 